
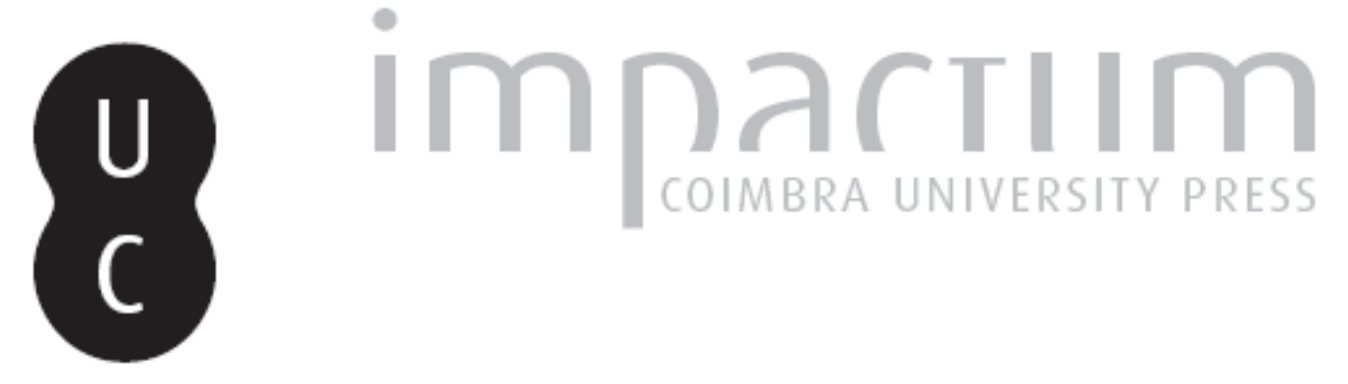

\title{
Art propaganda: the many lives of Picasso's Guernica
}

Autor(es): $\quad$ Ross, Sheryl Tuttle

Publicado por: Imprensa da Universidade de Coimbra

URL persistente:

URI:http://hdl.handle.net/10316.2/35517

DOI:

DOI:http://dx.doi.org/10.14195/0870-4112_11_19

Accessed : $\quad$ 26-Apr-2023 10:34:04

A navegação consulta e descarregamento dos títulos inseridos nas Bibliotecas Digitais UC Digitalis, UC Pombalina e UC Impactum, pressupõem a aceitação plena e sem reservas dos Termos e Condições de Uso destas Bibliotecas Digitais, disponíveis em https://digitalis.uc.pt/pt-pt/termos.

Conforme exposto nos referidos Termos e Condições de Uso, o descarregamento de títulos de acesso restrito requer uma licença válida de autorização devendo o utilizador aceder ao(s) documento(s) a partir de um endereço de IP da instituição detentora da supramencionada licença.

Ao utilizador é apenas permitido o descarregamento para uso pessoal, pelo que o emprego do(s) título(s) descarregado(s) para outro fim, designadamente comercial, carece de autorização do respetivo autor ou editor da obra.

Na medida em que todas as obras da UC Digitalis se encontram protegidas pelo Código do Direito de Autor e Direitos Conexos e demais legislação aplicável, toda a cópia, parcial ou total, deste documento, nos casos em que é legalmente admitida, deverá conter ou fazer-se acompanhar por este aviso.

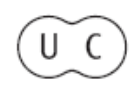




\section{ESTÉTICA E POLÍTICA}

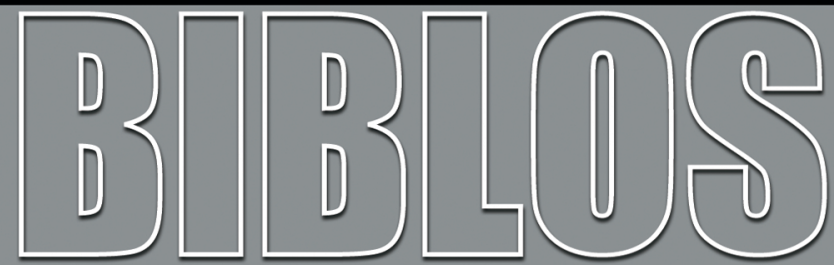

REVISTA DA FACULDADE DE LETRAS UNIVERSIDADE DE COIMBRA 
Biblos, n. s. XI (2013) 455-474

DOI: http://dx.doi.org/10.14195/0870-4112_11_19

Sheryl TutTle Ross

Philosophy Department

University of Wisconsin-La Crosse

\title{
ART PROPAGANDA: THE MANY LIVES OF PICASSO'S GUERNICA
}

\begin{abstract}
Guernica is almost universally recognized as anti-war propaganda, and its existence challenges long-standing views that art, properly speaking cannot be propaganda. The anti-art propaganda claim admits of varying degrees from its strongest articulation by Clive Bell who maintains that art and politics are mutually exclusive to Monroe Beardsley and R. W. Collingwood who maintain that propaganda is at best amusement art or that in so far as art is propaganda it gets in the way of its aesthetic value. This paper will argue that not only is Guernica a paradigm case of art propaganda, but that the epistemic merit model of propaganda can best account for the variety of propagandistic uses of this painting from its inception extending to modern day, in the contexts of the Spanish Civil War, Spain's transition to democracy, and most recently in the buildup to the Iraq War.
\end{abstract}

Keywords: Art Propaganda, Propaganda, Epistemic Merit Model, Guernica, Picasso.

\section{Resumo}

Guernica é reconhecida quase universalmente como uma propaganda anti-bélica, e sua existência questiona concepções tradicionais de que a arte propriamente dita não possa ser uma propaganda. A visão da arte como excluindo a propaganda admite diversos graus, passando de sua articulação mais forte por Clive Bell, que mantém que a arte e a política são mutualmente excludentes, até Monroe Beardsley e R. W. Collingwood, que mantêm que a propaganda é, no melhor dos casos, uma arte de entretenimento ou que, na medida em que a arte seja propaganda, seu valor estético se encontra comprometido. Esse artigo argumentará que não apenas Guernica é um caso paradigmático de arte como propaganda, mas que o modelo de propaganda como mérito epistêmico é o que melhor dá conta da variedade dos usos propagandísticos dessa pintura, desde 
sua criação até os dias atuais, nos contextos da Guerra Civil Espanhola, da transição democrática na Espanha e, mais recentemente, da preparação para a Guerra do Iraque.

Palavras-chaves: Arte como Propaganda, Propaganda, Modelo do Mérito Epistêmico, Guernica, Picasso. 
Guernica is almost universally recognized as anti-war propaganda, and its existence challenges long-standing views that art, properly speaking cannot be propaganda. The anti-art propaganda claim admits of varying degrees from its strongest articulation by Clive Bell who maintains that art and politics are mutually exclusive to Monroe Beardsley and R. W. Collingwood who maintain that propaganda is at best amusement art or that in so far as art is propaganda it gets in the way of its aesthetic value. This paper will argue that not only is Guernica a paradigm case of art propaganda, but that the epistemic merit model of propaganda can best account for the variety of propagandistic uses of this painting from its inception extending to modern day, in the contexts of the Spanish Civil War, Spain's transition to democracy, and most recently in the buildup to the Iraq War.

\section{Historical Reasons for Rejecting Art Propaganda}

When analyzing the very nature of art, a philosophical project which consumed aestheticians for most of the later part of the twentieth century, philosophers were aiming for definitions that accounted for all and only artworks. One thought experiment especially designed to get at our intuitions defining art invites us to imagine a warehouse where all and only artworks are located. The purpose here is not necessarily to identify how art functions, but instead to ask of all artworks what they have in common and how as a group they might be different from ordinary objects and events. The aesthetic experience or some notion of beauty became the focus of many theories. This approach leads to the conclusion that art qua art is not inherently or immanently political.

Clive Bell ascribes to the pure art view by maintaining that art should be autonomous from practical ends, a view that rules out a consideration of the overt dissemination of art propaganda as well as the view that all art cannot help but be ideological. Bell is perhaps the most strident proponent of the divorce between art and political concerns when he writes:

To appreciate a work of art we need bring nothing from life, no knowledge of its ideas and affairs, no familiarity with emotions. Art transports us from the world of man's activity to a world of aesthetic exaltation. For 
a moment we are shut off from human interests; our anticipations and memories are arrested; we are lifted above the stream of life. The pure mathematician, rapt in his studies, knows a state of mind which I take to be similar if not identical....Both he and the artist inhabit a world with an intense and peculiar significance of its own; that significance is unrelated to the significance of life. ${ }^{1}$

The aesthetic experience as Bell describes it above, is not in the least related to other human endeavors. What defines art for Bell is its having significant form which gives rise to or causes an aesthetic experience. The significant form itself is both necessary and sufficient for our appreciation of art. This renders the content of the artwork insignificant as art does not sully itself in the mundane-it occupies a different sphere. Moreover, according to Bell, the spheres of art and politics are necessarily mutually exclusive.

One consequence of this view is that it cannot recommend any course on art appreciation as it is simply a feature of the human mind as a human mind that allows it to perceive significant form and thereby identify beauty, the hallmark of artworks. Given that there are entire academic disciplines of art history, art interpretation, and art criticism, Bell's view seems not to account for the significance and cultural impact art has. The restrictions implied by this purely formalist view, proved to be much too limiting as an overall theory, and it is no longer the prevailing one.

However, even if we adopt the position that a pure formalist view can identify works of art, it does not follow from this view that we must not consider politics itself or even political art as a legitimate area of inquiry, for there are other activities related to art, namely interpretation and evaluation that belong in the sphere of aesthetic inquiry as identification alone does not sufficiently exhaust our curiosities.

Some may be tempted to object by thinking of another set of formalists, namely Wimsatt and Beardsley, who have argued that the intentional fallacy rules out any sort of political analysis of art. Like Bell, Beardsley maintains that it is the aesthetic experience an artwork affords is its salient feature. Beardsley writes "aesthetic objects differ

${ }^{1}$ Clive Bell, Art, New York: Arrow Books, 1925 p. 36-37. 
from those directly utilitarian objects in that immediate function is only to provide a certain kind of experience that can be enjoyed in itself." ${ }^{2}$ Here Beardsley holds that political art is interesting only in so far as it can provide us with an aesthetic experience. However, for Beardsley the relationships among art, politics and morality is complicated as he allows that the semantic content of the artwork could be so morally atrocious that it would interfere with our appreciation of it. ${ }^{3}$ If we read the intentional fallacy as simply an admonition against taking the artist's word for the value and the meaning of a work of art (an admittedly deflationary reading,) then one may rightly interpret the meaning and value of political art as politics unproblematically.

R.W. Collingwood's approach allows for the consideration of political art even though he identifies the essence of art in the clarification of emotions. He writes "Art proper, as an expression of emotion...the artist proper is a person who, grappling with the problem of expressing a certain emotion, says, "I want to get this clear'."4 It is the act of purifying the emotions and not the material or the audience's response that makes art proper, art proper. There are times when there is a means-ends relationship between what is represented and what is perceived, however that is a sort of pseudo art. That is, Collingwood does consider magical art and amusement art as in a critical sense deficient with respect to art proper, but he does indeed consider them to be art. Moreover, he opens up a new possibility for inquiry. In addition to the questions Collingwood himself entertains, we might consider what it means to be political art qua political art. Following Collingwood's method or conceptual analysis, we might first understand the nature of propaganda and by so doing get clearer on how it is that art can be used propagandistically. One test of the adequacy of the conceptual analysis will be whether it can account for the fact that one and the same work of art has been used for different propagandistic ends. The last section of the paper will demonstrate just that.

${ }^{2}$ Monroe Beardsley, Aesthetics: Problems in the Philosophy of Criticism, New York; Harcourt, Brace \& Company, 1958, p. 572.

${ }^{3}$ Monroe Beardsley, Aesthetics...., cit., p.558-583.

${ }^{4}$ R. W. Collingwood, The Principles of Art, Oxford; Oxford University Press, 1958. P. 33-50. 


\section{The Epistemic Merit Model of Propaganda}

If the aim is to get clear on the political nature of some art, then it is useful to start with a paradigmatic case of the political. Propaganda is intentionally and expressly political, and although not all cases of propaganda are cases of art propaganda, if we get clearer on the nature of propaganda, then we can more easily theorize about the nature of a subset of propaganda: art propaganda. Propaganda itself has been a long standing interest of philosophers, dating back to Plato's time. His ambivalence is rather noteworthy as he both proposed a noble lie which would ensure social stability and argued that artists should be banished from the ideal state for the fear that the consumption of such art might cause its audience to be driven by an inferior part of the soul to actions harmful to both the person and to the state.

The development of various mass media, including mass market magazines in the 1880s, film in 1890s, radio in 1930s and television in 1950s gave rise to concerns about the impact of mass persuasion. ${ }^{5}$ These media were referred to as mass persuasion, and it did not initially have a negative connotation. One might argue that the advent of the mass audience began with the invention of the Gutenberg printing press in the fifteenth century. Nevertheless, an important part of the rise of the usage of the term "propaganda" is its relationship to the scope of its audience, namely a mass. The consequences of the potential for mass persuasion became a source of opportunity for some and a source of concern for others who were preoccupied with this seemingly new way of communicating.

The rise of propaganda grew hand in hand with the rise of modern advertising and public relations. During World War I, George Creel, a then famous advertising mogul, headed the Committee on Public Information which was tasked by President Woodrow Wilson to enlist public support for the United States entrance into an unpopular war with Germany. Among his tactics were to employ seemingly ordinary movie theater-goers as plants in the audience where just before the newsreels played, they would cause a disruption in the audience by beginning a

${ }^{5}$ Sheryl Tuttle Ross, The Epistemic Merit Model and Its Application to Art, in Journal of Aesthetic Education, vol. 36 no.1 Spring 2002 p. 16-30. 
conversation about war atrocities occurring in Europe. ${ }^{6}$ Creel boasted of his accomplishments in the book How We Advertised America. Thus, began the cozy relationship among advertising, public relations and propaganda. This example also embodies both the pejorative and the neutral sense of propaganda as those who use it to advance their aims are often sanguine about its potential effects, while those who are the targets of propaganda campaigns do not share their views.

Any comprehensive definition of propaganda must accommodate both the pejorative and neutral sense of propaganda as there have been Ministries of Propaganda in many countries, and many health promotion campaigns are referred to as propaganda in a positive or neutral light; however, some kinds of propaganda constitute a violation of human rights as recognized by the U.N Charter. One provision of the Resolutions adopted by the General Assembly reads, "the General Assembly 1. Condemns all forms of propaganda, in whatsoever country conducted, which is either designed or likely to provoke or encourage and threat to the peace, breach of the peace, or act of aggression." ever, in that very same document, the U.N Charter states "To promote, by all means of publicity and propaganda available to them, friendly relations among nations based upon the Purposes and Principles of the Charter" ${ }^{\prime}$ Hence, the effects of propaganda are estimated to be either relatively benign, perhaps even helpful or a serious threat to the peace. Moreover propaganda has many guises-- it can be a fireside chat given by a president, a pop song, poster, a dramatic play or a pamphlets. The International War Tribunal for Rwanda indicted the pop artist Simon Bikindi making him the only artist to be tried for crimes against humanity and inciting genocide through his artwork. Clearly, if such a case can go forward in an international law court, then an account of propaganda that deals with a range of cases is necessary.

If propaganda is an act of political persuasion, then this suggests a distinction between ideology and propaganda. Ideology might be

${ }^{6}$ George Creel, How We Advertised America (Harper and Brothers 1920) p $1-36$.

${ }^{7}$ The UN Documents Gathering of Global Agreements November 3, 1947. (http://www.un-documents.net/a2r110.htm, accessed at 2013.06.30).

${ }^{8}$ The UN Documents... op cit. 
thought of as world-views, mind-sets or myths abroad in a culture. ${ }^{9}$ Thus, Liberalism, Conservatism, Progressivism, Hinduism, Christianity, Buddhism, Consumerism, are all ideologies. Of course, ideologies are not necessarily coherent, and are often beliefs held unreflectively. Furthermore a particular individual may hold inconsistent ideologies. These mind-sets describe the cultural context within which propaganda occurs. Thus, propaganda is distinct from ideology in that propaganda is an intentional act of political persuasion whereas an ideology is a mind-set or collection of ideas, and not necessarily an act at all. We should be clear at this point that the fact that these two phenomena are distinct does not mean that they are mutually exclusive. For often it is the ideologies that are motivating and informing the act of political persuasion. The distinction is nevertheless important because intentions are morally relevant properties in our assessments of actions. The moral assessment of propaganda is especially important as we turn to propaganda's pejorative sense. Thus, the neutral sense of propaganda equates propaganda with mere political persuasion. ${ }^{10}$ We might add the caveat that those involved in this persuasion are not interested in dialogue, but instead focused on a specific message, messages or agenda. One test to distinguish propaganda from sincere public discourse is to see whether the person advancing the message could change her position publicly in the face of evidence.

Propaganda has come to mean much more than mere political persuasion and as such the term is often used disparagingly. That is, if a politician is labeling an opponent's commercials as propaganda, the politician is not simply saying that the opponent is simply engaging in political persuasion, but often insinuates that the opponent is lying or trying to manipulate public opinion. There is an epistemic component in this accusation as those that advance propaganda are intentionally tinkering with the proper formation of beliefs.

We might capture the pejorative sense of propaganda with the following definition:

${ }^{9}$ Terry Eaglton, Ideology: An Introduction (Verso: New York 1991) p. 2-19.

${ }^{10}$ This is a prevalent definition found in the following works: William HumMELl and KeIth Huntress, The Analysis of Propaganda (New York: Holt, Rinehart and Winston, 1949) p. 2.; A Group Leader's Guide to Propaganda Analysis (New Haven: The Institute For Propaganda Analysis, 1938) p. 41. 
Propaganda $=$ an epistemically defective message ${ }^{11}$ designed with the intention to persuade a socially significant group of people on behalf of a political institution, organization or cause.

This definition invokes a broadly Gricean framework of communication where a speech-act is not simply analyzed by virtue of its semantic content but takes into account the speaker's intentions, the semantic content, and the relation between the semantic content and the likely uptake of the intended audience. ${ }^{12}$ What makes this account broader than perhaps what Grice envisioned is that a message need not be written, stated or spoken, but can also be conveyed through actions and pictures. ${ }^{13}$ Epistemic defectiveness is therefore broader than the traditional notions of truth and falsity, although the truth-value of a message is certainly relevant in our assessment

We can further define epistemically defective.

A message is epistemically defective if it is false, inappropriate, or connected to other beliefs in ways that are inapt, misleading or unwarranted..$^{14}$

The semantic content is relevant- for being false is a sufficient condition for a message's being epistemically defective. However, it is not necessary for the message to be false in order to be epistemically defective. To illustrate, we can consider the slogan "no other aspirin is proven more effective." The sentence itself is true. However, the message is epistemically defective because it is intended to lead one to believe that Bayer aspirin is the best aspirin whereas we are only warranted to believe that given the same chemical component it is no better and no worse than other brands including generic brands. The Bayer commer-

${ }^{11}$ I borrow this term from Noel Carroll, he uses it in "Film, Rhetoric and Ideology" in Theorizing the Moving Image (Cambridge, Cambridge University Press: 1997) p. 285.

12 Paul Grice Studies in the Ways of Words (Cambridge: Harvard University Press 1989) p. 86-143.

${ }^{13}$ Grice was interested in showing the action component in speech. I take this one step further to analyze the semantic component in some actions and words. This is not without its own set of problems.

${ }^{14}$ I have added inapt to this definition. I suspect that there are other ways that my definition is broader than Noel Carroll's. 
cial slogan is defective by virtue of the message's seemingly natural but unwarranted connection to the audience's other beliefs.

A message can also be epistemically defective because it is inappropriate or inapt. The features of an inappropriate and inapt message are in part an inappropriate emotional appeal or inappropriate moral dictums as well as inapt metaphors that trade on the prejudices of the audience. ${ }^{15}$ For example, the Nazi film Jud Suess which depicts Jewish persons as rats trades on an inapt metaphor because it aims at fueling the already present anti-Semitic attitudes in the culture. It should be understood that not all emotional appeals are epistemically defective, for there are certain times that appealing to emotions are warranted. The international news depictions of the effects of wildfires, tornadoes or hurricanes cause viewers to feel compassion, and this seems to be both a very human response, and a necessary emotion for an appropriate moral response to such a tragedy.

Propaganda in the pejorative sense is still a species of political persuasion. In fact, what separates the neutral and pejorative sense of propaganda is the epistemic defectiveness of the message. I call this the epistemic merit model of propaganda. All propaganda is political persuasion that aims at a socially significant audience. ${ }^{16}$ There are four discernible necessary and jointly sufficient conditions: 1) an intention to persuade 2) a message 3 ) a socially significant audience 4 ) on behalf of a recognizable political institution, organization or cause. What distinguishes the neutral from pejorative sense is the lack of epistemic merit in the case of the pejorative use of the term. We should contrast this approach to two other prevalent strains of definitions in the current literature. One definition focuses on rationality.

F.C. Bartlett and Randall Marlin each define propaganda by contrasting it to rationality. Bartlett write "propaganda is an attempt to

15 Thus, the notion of epistemic defectiveness can capture artistic means of conveying propaganda while allowing that some art can have epistemic merit.

16 The audience of propaganda may but need not be linked to each other. A socially significant group of people could be as broad as groups dividing along the dimensions of race, sex or age or the relevant group might even be narrower such as the readership of The Nation. It may be that the subject matter of a particular piece of propaganda is only of local interest, and therefore the socially significant group it addresses is restricted to certain geographical locations such as local elections or school board races. 
influence public opinion and conduct-especially social opinion and conduct-in such a manner that the persons who adopt the opinions and behaviors do so without themselves making any definite search for reasons." ${ }^{17}$ Marlin writes that propaganda is "the organized attempt through communication to affect belief or action or inculcate attitudes in a large audience in ways that circumvent or suppress an individual's adequately informed, rational, reflective judgment." ${ }^{18}$ Both of these definitions capture many of our intuitions about propaganda. Propaganda does involve an attempt to influence an audience's beliefs, attitudes or behaviors and further does not promote adequately informed decisionmaking. The advantage of the epistemic merit model of propaganda is that it offers more details on how propaganda functions. It more readily distinguishes between the neutral and pejorative sense of propaganda, and asks the propaganda critic to consider the intentions of the propagandist, the content of the message, and how that content interacts with the beliefs that the intended audience is likely to have. As such, it gives a more robust description of how propaganda functions within society.

The range of neutral to pejorative senses of propaganda admits of degrees, and it accords with many of our judgments about propaganda. There is an obvious difference between the film Triumph of the Will and the leaflet that a candidate for city council drops at one's door. If the epistemic merit model is accurate, propaganda is, at a minimum, political persuasion that aims at a socially significant audience, and in the pejorative sense, propaganda entails an epistemically defective message designed with the intention to persuade a socially significant group of people on behalf of a political institution, organization or cause. We should note here that the scope of the intention is ambiguous between an attempt to persuade using an epistemically defective message, and an attempt to deceive using an epistemically defective message. I think that both of these phenomena are part of the pejorative part of propaganda, but we can separate them when we consider the ethical and political import of propaganda.

${ }^{17}$ F. C BARlett, "The Aims of Political Propaganda" (Octogon: New York 1940) p. 6

${ }^{18}$ Randal Marlin, Propaganda and the Ethics of Persuasion. (Broadview: 2002) p. 22. 
Another virtue of the epistemic merit model is that it can account for the fact that art has been used propagandistically throughout centuries of art history. The recognition of and philosophizing about art's potential pragmatic function has been assiduously avoided in most philosophies of art. If we consider the pragmatics of art, then it will not necessarily be the artist who is the propagandist, the message may change given the background conditions or the likely mindset assumed by the political purveyor of propaganda, and one and the same work of art can be used propagandistically for differing ends. We can see this most clearly in a paradigmatic case of propaganda: Picasso's Guernica.

\section{Guernica as Propaganda: Three Case Studies}

Picasso's Guernica is one of the most easily recognizable pictures in the world. Reproductions of the image grace college textbooks and can be found on the walls of public institutions around the world, including the U.N. We can analyze the different propaganda functions and meanings of this work by addressing the following conditions of the epistemic merit model: a) an intention to persuade b) using an epistemically defective message or a message with political designs c) a socially significant group of people d) on behalf of a recognizable political institution, organization or cause. This modified communication model is relatively easy to use and by becoming clear on each condition of the four necessary and jointly sufficient conditions, we can assess meaning and impact of art propaganda. We will consider this one image, the Guernica, in three different propaganda instances: the Spanish Civil War, Spain's transition to democracy and the U.N. Security Council's meeting about the Iraq War.

As the most prevalent artwork depicting the horrors of war, Guernica, has its origins in the Spanish Civil War (1936-1939) between the Nationalists and Republicans resulting in the installation of a dictator: Francisco Franco. The Second Republic, a democratically elected government, was subjected to an attempted coup by a coalition of forces against various policies and social changes, including the secularization of Spanish culture. The Nationalists were able to overtake many Southern cities quickly; however, the Republicans had strong holds in 
Madrid, Barcelona and other Northern towns. Russell Martin sets the scene that motivates the artwork as follows:

By the time the bombs rained out of the spring sky in Gernika, the Basque countryside that cradled the town - and the rest of Spain as well-had been at brutal war for nearly a year. The democratic national government, to which so much of the world had looked with hope for six years, already appeared to be in great peril. Spain, like countries throughout Europe at the time, was caught in a bitter intellectual struggle between those who believed in the firm arm of fascism could best steer the course out of economic miasma of the 1930s, those who were equally convinced that Marxism lit the way to a better world, and the anarchists and democrats of dozens more political perspectives who were horrified by the two impassioned extremes. ${ }^{19}$

One of Spain's most famous museums is the Museo de Prado. It contains masterpieces from Hieronymus Bosch to Francisco Goya. "On 19 September President Azana, fully aware of the propaganda potential, and at the behest of his Director of the Prado, Jose Renau, offered Picasso the post of Director of the Prado." ${ }^{20}$ Picasso accepted this position even though at this point in his life he was an ex-patriot, living in France. During the Spanish Civil War as Madrid was under siege, the rich with priceless artworks were evacuated to Valencia at the same time as the retreat of the government. ${ }^{21}$ Although Picasso himself was living in Paris at the time, it was clear that his sympathies were with the Republican cause, and he vowed to make whatever impact he could. That art can be expressly political is a view expressed by Picasso in a famous interview:

What do you think an artist is? An imbecile who only has eyes if he is a painter, or ears if he's a musician, or a lyre at every level of his hear if he's poet, or even, if he's a boxer, just his muscle? On the contrary, he is at the same time a political being, constantly alive to heart-rending, fiery or happy events to which he responds in every way. How could it be possible

\footnotetext{
${ }^{19}$ Russell Martin, Picasso's War New York: Penguin Group 2002. p. 10.

${ }^{20}$ Gius Van Hensbergen, Guernica: The Biography of a Twentieth Century Icon New York: Bloombury, 2004. p.23.

${ }^{21}$ Gils Van Hensbergen, Guernica.... Op cit. p. 25-30.
} 
to feel no interest in other people and by virtue of an ivory indifference to detach yourself from the life which they so copiously bring you? No, painting is not done to decorate apartments. It's an instrument of war for attack and defense against the enemy. ${ }^{22}$

His sentiments were put into action when in January 1937 Josef Renau, Director General of Bellas Artes and Josep Luis Sert commissioned Picasso to create an exhibition for the World's Fair opening in Paris in April 1937.

The first condition of the epistemic merit model is thereby met. That is, there is a clear intention to persuade as not only was Picasso commissioned to create the mural, those who commissioned the painting had a voice in its ultimate presentation. The painting was due for the opening of the exhibition in April 1937, but as is the case with many projects created for World's Fairs this one was seriously behind sched$u^{23}$. In fact work did not begin on the mural until April 1937 which may say something both about the artist and his tendency to procrastinate, attributable in part to distractions caused by difficulties in several personal relationships, and about what a tumultuous time it was in Europe. The Spanish Pavilion itself opened seven weeks late..$^{24}$ Guernica itself was the subject of mixed reviews even from its inception. Those who charged Picasso with creating this mural had some say in how it ultimately turned out. The changes in the content of the painting made after a visit to Picasso's studio capture the relevant intentions is recorded in an unpublished letter by Josep Renau. The letter appears to be addressed to Jose Luis Sert and Luis Lascasas indicating that they are the Pavilion's architects. ${ }^{25}$ The letter begins with a description of Dora Maar, Picasso's lover and the photographer who documented Guernica's coming into being. It describes one version of the mural as covered in color and visually incoherent. Renau writes "por cierto que

22 Gils Van Hensbergen, Guernica... Op cit. p. 64.

23 Gils Van Hensbergen, Guernica... Op cit. p. 25.

${ }^{24}$ PBS Treasures of the World, Guernica, http://www.pbs.org/treasuresofthe world/guernica/glevel_1/3_pavilion.html accessed 06/15/2013.

25 Josep Renau, Unpublished letter in which Renau tells of how Picasso created Guernica, located in Museo Reina Sofia, Material Especial, Reserva 933, viewed on Novemeber 24, 2006. 
yo no he visto nunca mas mierda en la vida." ${ }^{26}$ I would translate this as saying that he had never seen so much shit in his lifetime. He further describes the encounter as

Y dijo - que les parace tenia pegados alli trozos de papel, de telas de cosas en caen y habia cosas en color que estaban dibujandos con carbon y no dijimos nada. Entonces el tio derepente agario todo el papel, todo lo que habian pegado y se fue agarro un pote y empezo a removerlo y embadurno con el lienzo y le quito el color....no se porque pero nostros concidemos espontamenente en aplaudiile.

I translate the passage as follows

And I tell you that it seems there was clutter everywhere and colors and charcoal used on the mural, but we did not say anything. Then all of a sudden he had changed everything that had been everything that had been attached to the mural and removed everything all color on it. When we saw this we all applauded spontaneously.

Picasso is reported in this letter to have said "Tienes razon Espana no se puede pintar mas que en el blanco y negro verdad"27 which means that you are right, One cannot paint Spain in anything more than the black and white truth. This letter is extremely revealing as it shows the power that the commissioners had on the ultimate shape of the mural. Renau had described the earlier version of the painting as "feo de feismo" or even uglier than ugly. The message of the mural of the war atrocities committed by the Nationalists signaled by the bull and the heroic, defiant Republicans shown by the horse's up -turned head was intended to garner sympathy for the Republic's cause. The earlier version sketched with the horse's head turned down seemed to indicated the Republic was already in defeat - a message rejected by those who commissioned the painting. Clearly the fact that this painting was commissioned by the Republicans meets the political condition of propaganda as it is a recognizable political organization, institution and cause. The chaos of the mural where the literal destruction of civilization seems inevitable, where even the women and children are not safe, and where

\footnotetext{
${ }^{26}$ JOSEP RENAU, Unpublished letter op. cit.

27 Josep Renau, Unpublished letter op cit.
} 
the light in the middle of the canvas shows the dual faces of modernity as its potential to illuminate and destroy are evident. Technology which enables one to supersede nature by illuminating the darkness has been twisted and used to enable the darkness of death, mass death.

So with the intention condition, the political condition both met, all that remains is a description of the audience as being socially significant and the epistemic merit of the message. The first audience is fairly obviously the international community attending the 1937 World's Fair. The audience soon enlarged to include the artworld as Cahier's d'Art dedicated a whole double-issue to its interpretation and evaluation. ${ }^{28}$ The message is clearly pro-Spanish Republicans and anti-Spanish Nationalists and Fascists. It is the figurative depiction of the literal destruction of a Spanish village, marking the first time in modern warfare that women and children were subject to the same conditions as the combatants themselves. The message itself seems to be epistemically merited; however, its original audience did not consider it so. The work was widely panned as a "hodgepodge of body parts that any four-year-old could have painted." 29 It was also regarded as a depiction of "useless horror which cannot reach more than a limited coterie of aesthetes." ${ }^{30}$ This is where a closer examination of the audience is called for as Guernica did influence those with money and political power. After the World's Fair the painting itself traveled to many locations in England, including Oxford, Leeds, London, Manchester, before finally arriving in New York for safe haven until Spain herself was once again a democratically governed country. Hence the work itself has an epistemic message with political designs. Picasso expressed his ultimate intentions for his work "If peace wins in the world, the war I have painted will be a thing of the past... The only blood that flows will be before a fine drawing, a beautiful picture. People will get too close to it, and when they scratch it a drop of blood will form, showing that the work is truly alive." 31

Some may at this point retort that Wimsatt and Beardsley have declared the intentions of the artist or author as irrelevant. One may still hold the intentional fallacy as a fallacy qua art, but not qua propaganda.

\footnotetext{
${ }^{28}$ Gils Van Hensbergen, Guernica... op. cit. p. 23.

${ }^{29}$ Gils Van Hensbergen, Guernica... op. cit. p. 23-29.

${ }^{30}$ Gils Van Hensbergen, Guernica ... op. cit p. 76.

${ }^{31}$ Gils Van Hensbergen, Guernica... op. cit p. 53.
} 
That is, just as one might regard a sheet of music as beautiful wallpaper or as notations to make music, a mural may be regarded as propaganda and as art even if one views the interpretation of art proper cannot make reference to intentions. For propaganda is not art proper, it is art with a purpose.

The placement of the mural itself became an important propaganda moment. Picasso himself demanded that the mural be returned to Spain only when it became a full-fledged democracy, and involved himself with negotiations about Guernica with the Museum of Modern Art (MOMA) in New York. By this time the artworld had fallen in love with the mural as it was treated as the crowning achievement of the modernist wing of the MOMA. The mural took on special meanings during the Vietnam War; however these meanings are outside the scope of this paper. So although the world had come to embrace the mural as a symbol of the horrors of war, it had a special resonance for Picasso's fellow countryman. "For many Spaniards who visited New York for their first encounter with Guernica, the experience was far more visceral and emotionally charged...the pilgrimage to MOMA represented a spiritual homecoming." 32

Although the history of the negotiations is complicated we might reduce them to their simplest form by using the epistemic merit model to show how the placement of Guernica functioned propagandistically. The political institution, organization or cause can be thought of as the post-Franco Spanish government who purchased the mural in September 1981, who leveraged the mass appeal of the artwork to show the legitimacy of the Spanish government in it transition to democracy. The socially significant audience is clearly the citizens of Spain herself, but united citizens of Spain, and not the fractured Spain of its Civil War. The epistemic message of the act of the return described by El Pais art critic, Francisco Calve Serrarller as "the return of our national dignity... it's exile has always been an offence to our dignity... and highlighted our inability to live in peace." 33 The intention condition is met by a shared intention. It was clearly Picasso's intention that the ultimate home for Guernica should be in the institution he was once the director of - the

\footnotetext{
${ }^{32}$ Gils Van Hensbergen, Guernica... op. cit p. 284.

${ }^{33}$ Gils Van Hensbergen, Guernica... op. cit p. 303-304.
} 
Prado. However, Picasso himself had passed away before his intention could be realized. The first intention to return Guernica to Spain after Franco's death was by an art history professor-Herschel Chipp who had done extensive research on the mural. He wrote an open letter to the New York Times in which he rehearsed Picasso's view on the ultimate resting place for the work. Negotiations with Picasso's heirs led the Spanish Government purchasing the work. Guernica whose image depicting the horrors of war message had changed because of the placement of it in the Casa de Buen Retiro marked an age of peace.

There have been other battles about the Guernica's placement. When the Guggenheim Museum in Bilbao opened there were calls to have the mural moved to it. However, in Picasso's writing it is clear that he intended the work to be housed at the Prado. Nevertheless replications of the mural are found worldwide, and even it replication can have profound propaganda value.

A replica tapestry of the mural or simply the image itself was feared to have propaganda power in rather recent noteworthy example. In 2003 the veiling of this masterpiece is seen as necessary before the United States Secretary of State, Colin Powell spoke in an effort to gain U.N approval for the Shock and Awe mission, bombing Iraq while the image of Guernica adorned the outside corridor of the Security Council chamber room. The official story about the need to cover the mural is that it would have made for bad television, the chaotic background proving too confusing for viewers. The official story is consistent with a view of the mural's propaganda power, for the chaotic background was not simply visually busy, but rather depicts the aftermath of the kind of modern bombing first done in Guernica that has become widespread as collateral damage is simply one of the phrases used to describe theaters of war. So much so that many journalists and critics were quick to point out that the now received message of the mural as "the horrors of war" conflicted or created epistemic defectiveness in the message Colin Powell was there to convey. The political condition is clearly met by the U.S. The socially significant audience was clearly all of those with access to media coverage. The intention to persuade is clear as well because the veiling of the mural required an intentional action in order for it to be done. The epistemic merit of the action is well-expressed by Laurie Brereton when she opined 
Throughout the debate on the Iraq there has been a remarkable degree of obfuscation, evasion and denial, and never more so than when it comes to the grim realities of military action. We may well live in the age of the socalled "smart bomb", but the horrors on the ground will be just the same as that visited upon the villagers of Gernika... And it won't be possible to pull a curtain over that. ${ }^{34}$

It is remarkable that a work commissioned for the World's Fair has had such a widespread impact not only on the artworld, but as a nearly universal cultural touchstone. That Guernica is propaganda can no longer be in doubt, and equally as certain is the fact that Guernica is firmly ensconced in the canon of Western Art. By untangling the narrative of the history of this great work in terms of the four conditions 1) an intention to persuade 2) using an epistemically defective or politically charged message 3 ) a socially significant group of people 4) on behalf of a recognizable political institution, organization or cause, we can clearly make sense of its political impact, and of one of the ways art can function politically. ${ }^{35}$

\section{Conclusion}

The resistance many philosophers have had to considering the overtly political uses of some works of art neglects the fact that art itself has been used propagandistically throughout the ages. The fear that one may reduce art to politics if one interprets the political function of specific artworks is ill-founded. For it is completely compatible to interpret artworks using several methods of description and interpretation. As was demonstrated by the many lives of Picasso's Guernica, the Epistemic Merit Model is simply one framework for demonstrating the

${ }^{34}$ Quoted in Gils Van Hensbergen, Guernica... op. cit p. 2-3.

${ }^{35}$ I would like to thank Octavio Bueno for his help in translation, Renzo Llorente and the students at the St. Louis University of Madrid, Spain as well as Jenifer Terpstra and the audience at Art Department at University of WisconsinLa Crosse Colloquium Series for helpful comments on an earlier draft. Crystal Neely provided invaluable help while researching the Archives of the Museo Reina Sofia. 
political meaning inherent in some works of art. Moreover, by considering the intentions, the epistemic merit, the political organization or cause as well as the audience's uptake, an art critic can come to terms with the propagandistic power of some works of art. 